Secondary publication on the edoc server of the Humboldt-Universität zu Berlin

https://doi.org/10.18452/21574

This is an Accepted Manuscript of an article published by Taylor \& Francis in Urban

Research \& Practice on 11/03/2016, available online:

http://www.tandfonline.com/10.1080/17535069.2016.1156735

Originally published as:

S. Becker, M. Naumann \& T. Moss (2017) Between coproduction and commons:

understanding initiatives to reclaim urban energy provision in Berlin and Hamburg, Urban

Research \& Practice, 10:1, 63-85, DOI: 10.1080/17535069.2016.1156735

\title{
Between coproduction and commons: understanding initiatives to reclaim urban energy provision in Berlin and Hamburg
}

\author{
Sören Becker ${ }^{\mathrm{a}}$, Matthias Naumann ${ }^{\mathrm{a}}$ and Timothy Moss ${ }^{\mathrm{a}}$ \\ ${ }^{a}$ Leibniz Institute for Regional Development and Structural Planning (IRS), Erkner, \\ Germany
}

\begin{abstract}
This paper explores new geographies of coproduction emerging in urban energy politics. It analyses processes of remunicipalisation of urban utilities, involving the re-establishment of public ownership with a strong democratic and ecological agenda for governing energy infrastructures, with case studies of the German cities of Berlin and Hamburg. Seeking ways of understanding these developments which transcend conventional binaries such as public vs. private ownership or consumer vs. producer, we interpret them in relation to debates first about coproduction and then about urban commons. This latter concept, we argue, provides deeper analytical purchase on new grassroots energy initiatives and the politics that unfold in remunicipalisation conflicts, offering a new avenue for enriching research on the coproduction of energy.
\end{abstract}

Keywords: coproduction; commons; energy transition; Germany; remunicipalisation; urban governance; social movements 


\section{Introduction}

The rise of renewable energies not only represents a technological shift to smaller-scale generation facilities, but also involves new actors beyond energy corporations that engage in electricity or heat generation and thus become coproducers of energy services. In many European countries, among them Denmark, Germany and the Netherlands, the energy transition has resulted in a reshuffling of market shares, bringing to the fore a more dispersed actor constellation of municipal, cooperative or citizen-led initiatives involved in energy production (Hisschemöller and Sioziou 2013; Nielsen and Jørgensen 2014; Yildiz et al. 2015). Although energy corporations still retain their importance, and citizen-owned wind turbines, 'prosumer' photovoltaics and community-owned energy grids (Bruns and Ohlhorst 2011; Burger and Weinmann 2012; Jenssen, König, and Eltrop 2014) only paint part of the picture, these developments highlight the increasing involvement of new actors and new forms of governance emerging alongside new energy technologies.

This paper focusses on the role of social movements in processes of remunicipalisation in the two German cities of Berlin and Hamburg. Remunicipalisation here refers to the (re)establishment of utilities owned, at least partly, by the local state. This involves either creating a new utility, purchasing shares of an existing one or giving concessions to existing municipal utilities (Bauer 2012, 337). Such transitions in the ownership of organisations often coincide with shifts in the ownership of physical infrastructure, such as plants, grids and other distribution technologies. Cases of remunicipalisation are significant as they often reverse previous privatisations in the public sector, involve new actors in public service provision and open up new governance pathways in the respective cities.

Recent studies cite some 200 such cases of remunicipalisation since 2005 in the German energy sector alone (Berlo and Wagner 2013). Beyond that there are instances of remunicipalisation in the French water sector (Hall, Lobina, and Terhorst 2013), relating to electricity in the United States (Hess 2011), and in a number of sectors in countries of the Global South (McDonald and Ruiters 2012). While recently some literature has emerged on the multiple reasons and motivations for remunicipalisation and state activity as part of urban climate and energy policies (Matecki and Schulten 2013; Bulkeley, Castan-Broto, and Edwards 2014), this paper develops a somewhat different perspective by focussing on the involvement of social movements, their ideas and impact on urban governance in the course of remunicipalisation processes.

The ambition of this paper is not merely to describe this novel phenomenon of social activism for a new, more participatory kind of energy utility, but to interpret it as a contribution to scholarly debate on coproduction as a mode of collective resource management and service provision. In line with this special issue we, first, draw on the concept of coproduction, which 
has been discussed as a way to increase the quality of public services through the inclusion of 'clients' and 'consumers' in planning, managing and physically providing services such as water, education and security (Evans 1996; Ostrom 1972; Ostrom 1996). We, secondly, seek to supplement this body of scholarship by relating it to recent research on urban commons and processes of 'commoning'. Associated primarily with the remarkable body of work on the governance of common goods and common pool resources by Ostrom and her colleagues (Ostrom 1990; Ostrom 2008), a new strand of commons research is using the concept to analyse alternative forms of collective (re-)production to neoliberal privatisation (Angelis 2003; Bakker 2007; Linebaugh 2008; Radywyl and Biggs 2013).

We explore the analytical power of these two concepts with a discussion of two case study cities - Berlin and Hamburg - recently experiencing new approaches to public and citizen ownership of energy grids and services. Both cities have witnessed attempts to remunicipalise energy systems in new ways involving a number of participatory elements. In both cities social movements have organised referenda for re-installing public ownership of the cities' energy grids and cooperatives have emerged to buy shares in the grid operator.

Referring to these two cases and considering ways of interpreting them in terms of coproduction and commoning, this paper seeks to answer the following research questions: 1) How can the concept of coproduction raise our understanding of the propositions and governance visions expressed by these initiatives? 2) What added value can the notions of urban commons - in their more recent, critical sense - bring to the analysis of new forms of remunicipalisation?

In answering these questions, we will first introduce the different initiatives and forms of organisation that are enrolling citizens in energy provision or grid operation in Berlin and Hamburg, revealing how they transcend simplistic notions of public or private ownership. In Section 3 we discuss the classical and critical approaches to coproduction and commons as a prelude to exploring their analytical capacity to interpret the remunicipalisation initiatives in Berlin and Hamburg afresh in Section 4. We summarise the main findings and their implications for research on coproduction in Section 5. Methodologically, our research is based on the analysis of available official documents, an intensive study of the newspaper coverage in both cities and expert interviews that were conducted in 2013 (Berlin) and 201415 (Hamburg).

\section{New energy for Berlin and Hamburg: remunicipalisation and new actors}

\subsection{The German energy transition and development trajectories in Berlin and Hamburg}

In Germany, the energy transition (Energiewende) has not only yielded a huge build-up of 
renewable energy generation capacities from wind, solar and biomass plants. Most significantly, the feed-in tariffs guaranteed by the Renewable Energy Law (EEG) have spawned massive investment in local, decentralised energy systems (Couture and Gagnon 2010). As a consequence, citizens, farmers and municipalities have been motivated to invest in renewable energy facilities. In total, the generation of energy from renewable sources amounted to $12.4 \%$ of the gross final energy consumption in 2013 (Eurostat 2015). Out of the overall installed capacity of renewable electricity in 2012 only 5\% was operated by the four biggest energy corporations, while almost half of the entire capacity was held by private citizens and farmers (Trend:Research and Leuphana University Lüneburg 2013). Additionally, energy grids have become an issue, as concession contracts, previously concluded with the major 'Big Four' electricity providers in Germany (Vattenfall, e.on, RWE and EnBW), have come up for renegotiation. This has opened up a field of political negotiation, and even conflict, in some cities as the options of remunicipalising energy grids and forming local utilities represent a reversal of privatisation processes that were characteristic of the liberalisation of European energy markets in the late 1990s.

Turning to the two case-studies Berlin and Hamburg, their point of departure is very similar. Both cities look back on a long tradition of a local energy supplier: the Berliner Städtische Electricitätswerke Aktiengesellschaft (BEWAG) and Hamburgische Electricitätswerke (HEW) date back to the late $19^{\text {th }}$ century, although they were not publicly owned throughout the entire period. In the case of Berlin, the local enterprise even survived the period of the city's division and was reunited after the fall of the Berlin Wall (Moss 2014). Both utilities had their main field of interest in the electricity sector; both were among the largest German energy utilities in the 1990s. However, both were sold step-by-step to the Swedish state company Vattenfall around the year 2000. The main reasons were threefold: firstly, there was a fear that local energy utilities would not be able to withstand the rising competitive pressure after the liberalisation of the European energy market (for this 'dying local utility' thesis see Bontrup and Marquardt 2010, 354f.); secondly, the sell-off of public utilities and property was seen as a means to reduce public debt; and, thirdly, the prevalent neoliberal assessment of public ownership as unaccountable, inflexible and prone to corruption legitimised privatisation in the general public (Rügemer 2006).

While the history of the cities' energy utilities is largely comparable, the overall development of the two cities since the 1990s differs. While Berlin's aspiration to become a growing capital and global city have taken shape only slowly (Krätke 2001), Hamburg has managed to retain its role as one of the most important industrial centres in Northern Germany and a major European port as well as developing into a postfordist service agglomeration (Bauriedl and Wissen 2002). Against these wider urban development trajectories, both Berlin and Hamburg have become important sites of a local 'Right to the City' movement (Mayer 2012, Beveridge 
and Naumann 2016). This movement found expression in a number of protests and collective actions around issues of housing and urban development. A link to infrastructure was made in Berlin in the shape of a successful referendum to publish the contracts underlying the privatisation of the Berlin water utility in 2011, played out as an important strategic experience in challenging the local authorities (Beveridge, Hüesker and Naumann 2014). For Hamburg, a long history of controversy and conflict over its nuclear and coal-based power plants dating back to the height of anti-nuclear protests in the 1980s proved an important backdrop to today's developments (Interview Zukunftsrat). Explicating this context is important to understanding that recent energy initiatives are embedded in a broader context of urban social movements in both cities. In the subsequent two sub-sections we introduce the different initiatives, their proposed or practised models for the involvement of citizens and the degree to which they have created a community around urban energy issues. Here, we present the initiatives merely to illustrate how far their motives and operations extend beyond the issue of private vs public ownership.

\subsection{Cooperative vs. participatory public ownership: different organisational models in Berlin}

The future of Berlin's energy supply has attracted widespread attention since two initiatives, the social movement coalition Berliner Energietisch (Berlin Energy Roundtable) and the cooperative BürgerEnergie Berlin (Citizens Energy Berlin), proposed different organisational models as an alternative to the existing private-sector dominated model of energy provision. On the one hand Berlin is an illuminating case for comparing different organisational and ownership models for the operation of the city's energy networks. On the other, it allows for a deeper analysis of how collective and grassroots initiatives come to play a role and challenge urban energy policy (Blanchet 2015; Kunze and Becker 2015), as well as neoliberal urban governance in general.

\section{Berlin Energy Roundtable - for a participatory, ecological and socially just energy utility}

The Berlin Energy Roundtable is a grassroots social movement that campaigned for a new participatory form of energy utility in Berlin (Becker, Beveridge and Naumann 2015; Blanchet 2015). In 2010, even before the onset of a public debate over awarding the concession for the city's electricity grid, a small group of activists had published a concept paper on the formation of a possible new municipal utility, outlining that it should both produce electricity from renewable energy sources and provide participatory structures (attac Berlin, BürgerBegehren Klimaschutz, and PowerShift 2011). This concept laid the foundation 
stone for a movement that was coordinated by the Berlin Energy Roundtable, a grassroots coalition to campaign for the remunicipalisation of the electricity grid. It involved around forty different actors such as large environmental organizations, small NGOs, leftist activist groups and anti-gentrification initiatives, as well as some professionals from the field of renewable energy (Interview Roundtable Activist).

As it became clear that the city government - first run by the Social Democrats and the Left Party in coalition and from 2011 by the Social Democrats and the Christian Democrats would not support specific steps towards remunicipalisation, it was decided to organise a referendum to pressurise local politics (Interview Roundtable Professional). An elaborate law was drafted in a consensus-oriented discussion process within the Roundtable. The draft law laid out different stipulations for a so-called 'Citizens Utility' (Bürgerstadtwerk) that should be democratic, ecologically oriented and socially just. The draft foresaw public meetings, an Advisory Board with directly elected citizen representatives and an obligation to make core documents accessible to the public (Berliner Energietisch 2012). Additionally, the entity should serve as a means for increasing the share of renewable energy used in the city and take measures against energy poverty (ibid.). In its final step, however, the referendum failed on 3 November 2013 , as only $24.1 \%$ of the required $25 \%$ of the city's electorate approved the draft law, with the vast majority of these voting in favour of the referendum (Landeswahlleiterin Berlin 2013). It was, nevertheless, an impressive display of opposition to an incumbent utility that only narrowly failed. In the aftermath of the failed referendum the Energy Roundtable continues to put pressure on the city's energy policy.

\section{Citizen Energy Berlin - a cooperative with aspirations as an ecological shareholder}

Parallel to the calls for a participatory public utility as articulated by the Energy Roundtable, the cooperative Citizen Energy Berlin (BürgerEnergie Berlin) proposes a different organisational model for citizen involvement that is based on direct collective ownership. While the Roundtable chose the path of political pressure, the approach of the cooperative Citizen Energy Berlin is to purchase a share of the grid-operating utility as a citizen collective. Their central strategic goal is to gather enough capital to become a partner in a cooperation model in which a municipal (or private) utility holds a majority share of the grid operator and the cooperative controls up to $49 \%$ (Interview BürgerEnergie). Cooperating with a local utility from Southern Germany, Citizen Energy Berlin is one of the bidders in the concession process. Launched in 2011, it had 2,300 members and a capital shareholding of about $€ 11$ million by September 2015 (according to their website accessed on 20 October 2015). Members are mainly recruited from people genuinely interested in energy issues, spanning various social groups from students to pensioners (Interview BürgerEnergie). To 
become a member, you have to buy five shares at $€ 100$ each. It is, however, not a condition to be a citizen of the city of Berlin to become a member. As with the Roundtable's plans, the objectives of the cooperative cover ecological, democratic and social issues. Ecologically they aim to strengthen Berlin's potential to achieve an energy transition by earmarking $10 \%$ of profits for reinvestment in solar and cogeneration plants. Their attempts to advance democracy are embodied in the general design of the cooperative, which grants each member one vote and revenue according to the member's shares. In social terms, the cooperative argues in favour of cost reduction through energy-saving and efficiency measures. The core strategy of the cooperative to attract new members is to appeal to people both as an ecological project and as an opportunity to invest (Becker, Beveridge, and Naumann 2015, 81). Currently the cooperative is active in lobbying the local government to be incorporated into a future local utility as a minority shareholder.

\section{Impact and Outlook}

The existence and the divergent aspirations of the two initiatives have generated a highly polarised debate on the future of Berlin's energy grid, involving both financial arguments and those referring to the initiatives' goals (Moss, Becker, and Naumann 2014; Becker, Beveridge, and Naumann 2015). The incumbent concessionaire mobilised a campaign focussed on the quality of service provision in the past; other private suitors have also expressed an interest in gaining the concession. Above all, the Roundtable's campaign succeeded in altering the public discourse and pressurising the government into forming a public utility, albeit without a strong participatory organisational structure (Becker, Beveridge, and Naumann 2015, 82). This new utility, Berlin Energie, was later granted the concession for the gas network in the city - a decision that, however, resulted in a split within the administration as the Senator of Justice took legal steps against the move (Zawatka-Gerlach, Törne, and Keilani 2014). Additionally, no decision on the future of the concession for the electricity grid was taken; the concession with Vattenfall is still in place. In May 2015, the Senate devised an internal compromise concerning the electricity and gas network, not aiming for a full remunicipalisation of ownership, but for 'the best possible influence' on the utilities and longterm cooperation with an industrial partner (Zawatka-Gerlach 2015). While the prospects for remunicipalisation in Berlin are still contested, the city of Hamburg has already undertaken steps towards publicly owned energy facilities. 


\subsection{From Hamburg Energie to 'Our Hamburg - Our Network': increasing citizens involvement in Hamburg}

Though attracting less scholarly attention, Hamburg is also an interesting case for new forms of citizens involvement in local energy politics. As with Berlin, the city of Hamburg has witnessed a referendum on the remunicipalisation of its energy grids. In contrast to Berlin, the referendum succeeded by a narrow majority of $50.9 \%$. Additionally, the referendum was preceded by the foundation of the public energy enterprise Hamburg Energie in 2009. So while Berlin is informative in terms of different models of organisation, in Hamburg one can observe the first effects of remunicipalisation and the implementation of a majority referendum decision on the future of energy networks.

\section{A green public utility - the formation of Hamburg Energie in 2009}

Hamburg Energie is a public utility that was founded with a clear ecological orientation and later complemented with participatory provisions to include the voices of citizens and business clients. Against the background of a history of energy-related conflicts in the city, it was the plan to erect a new coal-fired plant of 1.6 MW that proved the most divisive issue in the early 2000s (Interview Zukunftsrat). In the course of this debate, the Green Party previously a strong opponent - came to form a coalition government with the Christian Democrats. While the administration approved of the plant, the Green Party was now given free rein to establish a public utility with a clear ecological mission statement (Norddeutscher Rundfunk 2014). Hamburg Energie was eventually founded and entrusted with the 'provision of energy for the general public and public institutions', the sale of 'climate friendly electricity (nuclear and coal-free)' and the responsibility to 'plan, erect and run municipal infrastructures' (as recorded in the Commercial Register). The new utility was very successful in both acquiring clients and setting up renewable energy capacities. At the end of 2013 the company served 80,300 customers with electricity and around 11,000 with a gas delivery contract (Hamburg Wasser and Hamburg Energie 2014). It has, as indicated on their website, built wind turbines, photovoltaic installations and various combined heat and power plants. Notably, Hamburg Energie was involved in various projects involving citizens, public institutions and local businesses. Additionally, a client advisory board (Kundenbeirat) was installed in 2012. Although this body only has a consultative function, a Hamburg Energie employee emphasised in an e-mail that the company would grant 'a transparent look into managerial decisions' and claims that 'critical opinions of its members are dealt with in a constructive manner'. The board is composed of 20 members, of which ten are private clients and ten represent organised interests and associations from Hamburg, such as the Tenants' Association and the Chamber of Commerce of the city. Its actual leverage over the business 
practice of the utility is, however, limited (Interview Maaß).

Hamburg Energie is in two ways different from most of the other newly founded local utilities in Germany. Firstly, it stands out in terms of its clear orientation towards the generation of renewable energy in close cooperation with local citizens and business. Secondly, installing a participatory body was another novelty - a response to pressure exerted by the referendum campaign.

\section{'Our Hamburg - Our Network'- a social movement for grid remunicipalisation}

As in Berlin, there was a referendum campaign in Hamburg for remunicipalising the energy grid. With Hamburg Energie active in the fields of energy generation and sale, the approaching expiry date of the concession with Vattenfall signified the advent of a new political conflict. Here, also, a group of social movement activists and representatives of environmental and social organisations gathered as early as 2010 to consider how to remunicipalise the energy networks. Later they formed the campaigning coalition 'Our Hamburg - Our Network' (OHON) highlighting the local character of possible remunicipalisation. There are four main differences to the developments in Berlin. Firstly, the campaign not only aimed at the remunicipalisation of the electricity grid, but also included district heating and gas networks. Secondly, the coalition encompassed both grassroots level social movements and larger organisations such as $B U N D$ (the German member of Friends of the Earth), the Consumer Advice Centre (Verbraucherzentrale) and the charity organisation of the Protestant-Lutheran Church (Diakonie). The latter mainly shouldered the campaign and supported it with their policy networks and organisational capacity (Interviews BUND, Interview Church Interview, OHON Campaigner). Smaller activist groups and NGOs such as 'Robin Wood' and 'Stop Moorburg Pipelines ('Moorburgtrasse stoppen') played a supporting role in the coalition, as did the network 'Enterprises Against Nuclear Power'. Thirdly, the text subject to the referendum only consisted of two sentences, demanding the transition of the city's grids into public ownership and a 'socially just, climate compatible and democratically controlled energy provision from renewable sources' as a 'mandatory target'. Fourthly, the referendum was successful with a very narrow majority of $50.9 \%$ of the valid votes (Behörde für Inneres und Sport Hamburg 2014). Again in contrast to Berlin, it was only after the referendum that an 'Energy Roundtable' was initiated by grassroots activists to supervise its implementation. Although the Hamburg referendum law was less elaborate than that in Berlin, the OHON campaign in Hamburg showed how a coalition of established actors was able to successfully mobilise and challenge urban energy governance. 
Energy Network Hamburg - a cooperative re-orienting its strategy

As in Berlin, Hamburg has a cooperative that has sought to gain a share of the grid operating utility. As it largely followed the model of Citizen Energy Berlin we need only address its achievements here. Called Energy Network Hamburg (Energienetz Hamburg), it was more successful in terms of gathering capital investment than its Berlin counterpart: according to a press release from September 2013, some 3,000 members have accumulated more than 50 million Euro. The cooperative was one of the bidders in the concession awarding process cooperating with the Dutch utility Alliander. However, as the successful referendum requires full remunicipalisation by law, the cooperative Energienetz Hamburg is currently looking for other opportunities to invest. It developed a new strategy in May 2015 that targets investments in renewable generation capacities instead of grid ownership. In line with this new investment strategy it completed its first project, a citizen photovoltaic installation on the rooftop of an office building, in the summer of 2015. Further, Energy Network has been active in organising and participating in stakeholder dialogues on energy issues in the city.

\section{Impact and Outlook}

As in Berlin, the referendum campaign in Hamburg was successful in putting pressure on the local government and generating an intense and polarised public debate. During the first step of gathering signatures, the so-called Volksbegehren, the Senate signed a cooperation agreement with Vattenfall and e.on Hanse transferring into public ownership $25.1 \%$ of the shares of each of the district heating and grid operating branches of Vattenfall, and the gas grid operating branch of e.on Hanse. This partial remunicipalisation was accompanied by a catalogue of measures the power utilities agreed to, among them the development of virtual networks and cogeneration capacities for heat and electricity as well as targets for the reduction of $\mathrm{CO}_{2}$ emissions (Senatskanzlei Freie und Hansestadt Hamburg 2011). The hope that this step would silence calls for a full remunicipalisation of the grid, however, was confounded by the success of the referendum passing all the required preparatory steps. On the evening of the polling day the Social Democrat Party, hitherto involved in the campaign against the referendum, had to change its strategy and was forced to implement the will of the electorate. While the ownership transaction for the electricity network came into effect in early 2014 , the remunicipalisation of the gas and district heating networks was postponed as future options (Meyer-Wellmann 2014). Although there is wide criticism of how the ownership transfer has been conducted and how the principles defined in the second sentence of the referendum text have been implemented, it is argued that the success of the referendum has paved the way for more stakeholder participation in the governance of the city's energy system and beyond (Interview BUND, Interview SPD Environment, Interview 
Handelskammer). A number of energy-related discussions were convened, namely a "districtheating dialogue" and continuous representation of the initiators of the referendum in the city's Environment Committee, as well as other informal contacts and modes of consultation.

Taken together, the initiatives in Berlin and Hamburg advocate and advance new models of collective ownership in infrastructures. The cooperatives present a new model of citizen involvement in the running of core urban infrastructures, prioritising direct collective ownership. The forms of public ownership were - with the exception of Hamburg Energie initiated by non-state actors and social movements. These initiatives have not only been claiming public ownership as a form of indirect participation (Cumbers 2012) but also seeking to inscribe direct measures of participation into the utilities. Even in the case of Berlin, where they were not successful with the referendum, their effective mobilisation to have a say in local energy policy challenged established governance modes and actor constellations. From this vantage point we now explore how the concepts of coproduction and commons can raise our understanding of these initiatives beyond simplistic notions of public vs. private ownership.

\section{Coproduction and the commons: understanding citizen participation in urban infrastructure provision}

The concepts of coproduction and the commons are gaining increasing attention in the social sciences (on coproduction: Ostrom 1996; Verschuere, Brandsen, and Pestoff 2012; Osborne and Strokosch 2013; on commons: Ostrom 1990; Dietz et al. 2002; Angelis 2003; Bakker 2007; Hardt and Negri 2009). Although the two approaches are connected, they provide different, yet complementary starting points for analysing the transformation of energy provision in Berlin and Hamburg. Each of them develops a perspective on the provision or governance of public services involving more-than-state and more-than-business actors. In this sub-section we introduce coproduction and commons as two theoretical lenses through which to view and understand better the active involvement of citizens in the provision of urban services in general.

\subsection{The coproduction of public services}

Coproduction is a multi-faceted concept that spans a variety of themes and topics in development studies and public management scholarship, above all (new) models of public service provision especially in the Global South. It originated as a scientific term in the discussion on the complex and interdependent relations of various actors in delivering and maintaining certain public services in public management and administration theory (Osborne 
and Strokosch 2013, 33). It is strongly influenced by the work of Elinor Ostrom and others (Ostrom, Parks, and Whitaker 1974) from the 1970s onwards, looking at reforms in a number of sectors such as police, education, housing and water provision (Ostrom and Whitaker 1973; Ostrom 1996; Albrechts, 2013, 48). Ostrom also provided the fundamental definition of coproduction as a 'process through which inputs used to produce a good or service are contributed by individuals who are not "in" the same organization' (Ostrom 1996, 1073). At its core, the concept seeks to overcome the traditional dichotomy of centralised public agencies responsible for planning and service provision vs. citizens reduced to passive 'clients' (ibid.). In contrast, the normative core assumption of coproduction research is that the participation and 'activation' of clients helps to improve the quality and stability of service provision. Clients become 'coproducers of public services' (Alford 1998; Osborne and Strokosch 2013). Clients may usually encompass citizens or 'third-sector' initiatives (Brandsen and Pestoff 2006), although some sources also mention small and medium enterprises as contributors to the coproduction of public services (Ostrom 1996, 1075).

A growing body of literature is devoted to elucidating different arrangements through which coproduction is realised. Bovaird (2007, 849f.), for example, lists different forms such as 'consultation', 'codelivery' and others; all of which are subsumed in the concept of 'coproduction'. Out of these, 'full user-professional coproduction' applies when 'users and professionals fully share the task of planning and designing the service, then delivering it' (ibid.). An earlier taxonomy developed by Brudney and England (1983, 63) distinguishes different types of coproduction according to the size of the involved group. An advanced form is the idea of 'institutionalised' coproduction introduced by Joshi and Moore, according to which a 'long-term relationship between state agencies and organised groups of citizens' exists and 'substantial resource contributions' from both sides are involved (2004, 31). For the remainder of this paper, we will follow a distinction made by Brandsen and Pestoff (2006, 497) between coproduction as 'an arrangement where citizens produce their own services at least in part' on the one hand and co-management and co-governance involving the production, planning and delivery of public services by third-sector parties on the other.

Recently, work on coproduction have been expanding the original concept by emphasising its potential to advance social inclusiveness and empowerment. Calabrò (2012) even suggests considering coproduction as an alternative to privatisation. The active role that citizens play in coproduction processes, it is argued, can contribute to social inclusiveness and citizenship (Osborne and Strokosch 2013). Most prominently, Mitlin discusses coproduction 'as a grassroots strategy to secure political influence and access to resources and services' (2008, 339). Coproduction, thus conceived, might strengthen both local organisations and provide knowledge about services and processes of social change to those involved (ibid., 357). In discussing and addressing needs, processes of infrastructure coproduction is also said to help 
the 'building of a strong, resilient and mutually supportive community' (Albrechts 2013, 46). This - it is argued - can empower local citizens in a broader political sense, rendering coproduction an enabling factor to challenge 'systems and processes of government in various dimensions' and to prepare citizens for a 'more substantive engagement with the political system' (Mitlin 2008, 353).

Against these recent extensions of the coproduction perspective to emcompass social inclusiveness and empowerment, critics of the concept question its openness and the resulting ambiguity it can induce in institutional, ownership and conceptual terms. McMillan, Spronk and Caswell argue that coproduction would 'include anything from public-private partnerships between the state and multinational corporations to wells managed by a community and a local non-governmental organization' (McMillan, Spronk, and Caswell 2014,202 ). The quest to open up the responsibilities of public agencies to a wider set of actors can be viewed as echoing the onset of neoliberal reforms and thought (Peck 2010). Critics further argue that coproduction was an entry point for privatisation blurring the responsibilities of the state and thereby reproducing social inequalities in terms of access to basic services (McMillan, Spronk, and Caswell 2014). Bearing this in mind, we see the value of using coproduction to advance knowledge on issues of citizen participation and involvement, and especially in overcoming the distinction between consumers and producers in public service provision. This way coproduction provides a conceptual angle to transcend simplistic notions of private vs. public infrastructure provision. However, criticism of the concept raises important issues of the need to address contextual factors, questions of ownership and fundamental visions of service provision. We therefore argue that the approach of coproduction alone is not sufficient to capture the breadth of the changes to urban infrastructure governance currently being negotiated in our two case study cities. To this end we now introduce the concept of the commons and its different readings.

\subsection{Commons, commoning and the right to the city}

Research on commons has a long pedigree. To understand the appeal of the commons and the different ways commons have been researched, it is helpful to categorise three schools of thought that have emerged since the 1960s. The idea of the commons first emerged in the 1960s when neo-classical economists developed a theory for classifying goods and services according to their excludability and rivalry (Olson 1965; Bromley 1991). Different permutations of these attributes produced the familiar matrix of four categories of goods: common pool resources, club goods, pure public goods and private goods. The purpose behind this exercise was to identify generic problems of providing and protecting collectively used goods in a market economy, such as free-riding through non-payment or externalised 
negative effects, and using the above categories to help identify suitable modes of provision, use and regulation.

In the 1990s a second strand of commons research arose around the work of Elinor Ostrom (Ostrom 1990; Dietz et al. 2002; Ostrom 2005; Ostrom 2008). Rather than deducing suitable institutions from theory, she and other institutional economists and political scientists have developed eight 'design principles' for the governance of the commons and a framework for institutional analysis and development (IAD) on the basis of a huge database of empirical examples of communities managing commons collectively drawn from across the globe (Ostrom 1990). This strand of commons research focuses primarily on (natural) common pool resources (CPR), such as water or fisheries, and has a clear normative preference for the management of CPRs being entrusted to local communities and polycentric governance structures. As with coproduction, the concept is open to different forms of ownership as 'a common-pool resource can be owned and managed as government property, private property, community property, or owned by no one' (Ostrom 2010, 650). Nevertheless, rights of use that are distributed within a community play a defining role in the commons concept (Schlager and Ostrom 1992; Fennell 2011). In short, this strand of commons research displays a strong focus on issues of governance in collectively managing a resource. The underlying trust in the benefits of stakeholder cooperation has, however, been criticised for paying inadequate regard to contestation and power relations over resource use (Harvey 2011, 102).

Since the early 2000s, and with recent intensity, a third strand of research on commons has developed alongside goods and institutional economics theory. This body of scholarship goes beyond institutionalist thinking and approaches collective modes of managing the commons not as a complement to market mechanisms and state regulation, but as an alternative. Inspired by neo-Marxist thinking (Harvey 2012) and green activism (Helfrich and Bollier 2012), this literature is interested in the emergent phenomena of post-capitalist forms of collective ownership and production (Angelis 2003; Bakker 2007) or 'participatory economics' (Hahnel 2015). It ascertains that commons are more than just commonly governed goods and services, but 'suggest alternative, non-commodified means to fulfil social needs' (Angelis 2003, 1). Commons in this sense constitute a 'common wealth' (Hardt and Negri 2009) of societies which should not be reduced to mere commodities. Likewise, the commons are here seen as both an alternative to, and endangered by, processes of enclosure and accumulation by dispossession (Bakker 2007; Harvey 2012, 148; Jeffrey, McFarlane, and Vasudevan 2012), such as land-grabbing and the depletion of global environmental commons.

Commons from this perspective are not given, but produced through discourse and practices. These activities of 'commoning' (Linebaugh 2008), or commons creation, are based on common interest and sharing. Generally, commoning challenges existing power relations and ownership structures as it is directed against logics of commodification, marketisation and 
privatisation (Von Winterfeld et al. 2012). In contrast to the openness towards different kinds of ownership in the work of Elinor Ostrom, a number of critical commons thinkers underline the necessity of state or at least collective ownership to ensure the creation of proper commons (Harvey 2012; Cumbers 2015). It follows that attempts to establish commons are often highly contested, as reflected in worldwide oppositional networks aspiring to 'a radical reclaiming of the commons' (Klein 2001, 82).

Recently, the work of David Harvey (2012) and others has been linking the debate on commons to critical urban theory, spawning a growing number of studies that seek to empirically underscore the idea of the commons as an alternative to capitalism in an urban context (Eizenberg 2012; Kip 2015). Nicholas Blomley (2008), for example, has developed the concept of 'urban commons' in this context, using a case study of a social protest movement against the development of a site in Vancouver's Downtown Eastside. Here, the 'urban' in urban commons is not just a denominator of location, but relates to alternative practices in the production of urban space (Eizenberg 2012; Susser and Tonnelat 2013). Examples of urban commons thus cover movements and assemblies that also display a spatial expression, such as occupy and squatting projects (Radywyl and Biggs 2013; Casas-Cortés, Cobarrubias, and Pickles 2014, 457f.). Against this, Susser and Tonnelat (2013) take a broader stance, including labour, collective production, arts and also public services in the list of urban commons.

Apart from identifying examples, this critical literature on the urban commons is interested in how the commons get produced through interaction and 'common practices' on different scales (Radywyl and Biggs 2013, 159). Parr $(2015,87)$ sees urban commoning as an outcome of three different processes that unfold in an interrelated way: a politics that seeks to build coalitions in anti-oppressive struggles on different scales, an alternative process of urbanisation and 'collaborative activities' to push back exclusive, private forms of ownership. In this sense, urban commons relate to new political imaginaries based on justice, but also require the ability to 'control and imagine governance in new ways' (Chatterton 2010, 627). They are simultaneously contested by processes of enclosure (Hodkinson 2012) and contesting market-based forms of fulfilling social needs. Commons, in this debate, are constructed as an alternative to neoliberal urbanism and as a vehicle for transformative urban politics.

\subsection{From coproduction to commoning}

Both core concepts in this paper, coproduction and the commons, are buzzwords in current debates on urban change towards more sustainable and, perhaps also, more democratic cities. Above we have described the development of both concepts and discussed the institutionalist 
and more critical approaches to each of them. While institutionalist understandings both of coproduction and the commons are connected with the work of Elinor Ostrom, attempts to explicitly combine both approaches are rare. Verschuere, Brandsen and Pestoff $(2012,1088 \mathrm{f}$.) highlight the condition of excludability in coproduction processes as coproduction is about 'the involvement of users in the delivery of goods that are at the disposal of a group of entitled users'. Accordingly, there has also been some debate on how coproduction can be grasped and regulated in organisational terms. However, here the focus lies on effectiveness and fit of coproduction to inter-organisational processes (Alford 1998) and the types of organisation that enable effective coproduction (Pestoff 2009). Accordingly, in the institutionalist reading of both terms there is some tacit acknowledgement that the two concepts are not mutually exclusive but complementary. In this reading, examples of coproduction could entail features of commons and vice versa. Additionally an explicit reference from both concepts to energy issues is still missing. While there is some work on energy as a common (Jenny, Hechavarria Fuentes, and Mosler 2007; Vermeylen 2010; Borenstein 2012; Wolsink 2012), there are so far no explicit notions of energy systems as urban commons.

The value of coproduction approaches lie undoubtedly in their focus on the integration of new actors into the management or provision of public services. We uphold, however, that the conceptual critique directed against the openness of coproduction towards privatisation and a variety of other organisational forms creates the need to include a wider range of contextual factors in the analysis. The notion of urban commons, we feel, can help to encapsulate this broader perspective and, at the same time, to build upon the recent critical strand of coproduction research.

While the concept of commons also addresses the governance of public services and the role of citizens therein, we argue that the active notion of commoning addresses issues that go beyond a narrow understanding of coproduction, in two ways. Firstly, coproduction is not explicitly concerned with questions of ownership and the character of the service provided (eg. commodity or common good) on a conceptual level. Secondly, despite normative claims that coproduction would increase the quality and democratic character of the services coproduced (Verschuere, Brandsen, Pestoff 2012, 1093f.), more clarity is needed on which visions of urban governance are generally associated with ideas of coproduction. 


\section{Discussion: urban energy provision as coproduction, energy utilities as urban commons?}

In Section 2 we presented energy initiatives in the cities of Berlin and Hamburg that formulate new models for how urban energy systems should be governed through citizen participation and according to sustainability targets. The initiatives represent different models of organisation, spanning cooperatives that seek to purchase shares in the grid operating utility, an established green energy provider subsequently complemented with participatory provisions and more wide-ranging proposals for embedding participation in local utilities. They also depict different forms of collective ownership, involving either direct membership in the case of the cooperatives or increased participation in local public utilities. Beyond that, both cities experienced a public debate that linked the issue of grid ownership to wider aspirations for renewable energy, social justice and democratic control.

In this section we discuss these developments through the lens of coproduction and the commons. More specifically, we will show how the concept of coproduction helps us to address and identify different forms and models of citizens' involvement in infrastructure governance. We will, however, also demonstrate the need to broaden this perspective with the notion of urban commons in order to account for the aspects of the initiatives inadequately captured by the concept of coproduction. This will also, on a more general level, show how the concepts of coproduction and the commons can be applied to analyse alternatives to the privatised provision of energy and other public services.

\subsection{Coproduction and energy utilities: going beyond consumers and producers}

The origin of research on coproduction is a reassessment of the possible role of consumers in the provision of public services, thereby increasing the quality and accountability of the services provided (Ostrom 1996; Verschuere, Brandsen, and Pestoff 2012). The direct involvement of citizens in service coproduction, it is claimed, also alters their relationship towards public or private service providers. While the constellation we have encountered in the cities of Berlin and Hamburg is different from the pre-privatisation or developing country contexts in which the concept was developed, we argue here that coproduction can serve as a heuristic to identify different models of how citizens can be involved in energy generation and grid operation on the city level.

While it is clear in each case that there is no strict distinction between consumers and producers in energy provision, it is important to deploy a working definition in order to delineate the contribution of coproduction research. We here refer to a narrow understanding of coproduction as proposed by Brandsen and Pestoff (2006) which sets as a core indicator the 
involvement of citizens in the production of services and distinguishes proper coproduction from co-management and co-governance. Applied to our examples we can identify three different ways in which coproduction is practised: coproduction on the project scale, coproduction through advisory boards and coproduction through partial ownership.

\section{Coproduction on a project scale}

Coproduction can take a number of forms with different levels of durability, resource intensity and institutionalisation (Joshi and Moore 2004). An accessible and relatively straightforward form is the involvement of citizens in projects with a clear aim and limited duration. This mode of coproduction that we term 'coproduction on a project scale' can be identified especially in a number of collaborative projects that were implemented by Hamburg Energie. A prime example of this type of coproduction is the ' $10 \mathrm{MW}$ project' already mentioned. Here, a great variety of state institutions, private enterprise and citizens were involved in installing a total of 11.3 MW solar power in a short period of time. The State Office for Geoinformation and Topographical Surveying (Landesbehörde für Geoinformation und Vermessung) created a 3D model of appropriate areas and rooftops for the installation of solar panels, the so-called 'solar atlas'. A variety of local enterprises - owning for instance, an aircraft construction site, port areas and warehouses - as well as the famous alternative football club St. Pauli, public authorities and schools made suitable land available. According to a self-released corporate video, the project was cofinanced by citizens, Hamburg Energie itself and local bank loans, with an investment volume of $€ 28$ million, of which $€ 4$ million were direct citizen investments. Significantly, it was the foundation of Hamburg Energie that created the organisational platform to implement coproduction projects in the first place. It provides an example of how remunicipalisation can create an institution that enables the involvement of citizens.

\section{Coproduction through advisory boards}

The second type of coproduction we could identify in the debates about public utilities is the installation of advisory or supervisory boards that involve citizens and other stakeholders. The installation of a consumer's advisory board in Hamburg Energie can be taken as an example of this kind of coproduction. Although it only has a consultative function, it involves both elected client representatives and organised stakeholders, such as the Tenants' Association and the Chamber of Commerce of the city. The numerous mechanisms for democratic control inscribed into the Berlin draft law of the Energy Roundtable illustrate other possible options for ensuring citizen influence in a utility. This type of coproduction is positioned in between 
the different modes of cooperation Brandsen and Pestoff (2006) have developed. It shows aspects of 'co-governance' as third-sector actors are involved in the planning of service provision, but also 'co-management' in the way that state and third-sector actors cooperate here. The establishment of consumer boards marks a significant difference to previous public enterprises, which in theory were accountable to the voters and public authorities, but in practice were able to act largely independent of public or popular control. In short, public utilities that allow for user participation provide openings for both kinds of coproduction to flourish.

\section{Coproduction through co-ownership}

The third form of coproduction we can observe in the initiatives in Berlin and Hamburg represents a novel approach to the coproduction of networked infrastructures. It refers to the possible option that one of the cooperatives might gain shares in the grid operator in the future. In this case citizens, at least the members of the cooperative, would become co-owners of the energy infrastructure. Enacted by contracts and the transfer of legal entitlements and duties to the collectively organised citizens, it would signify a highly institutionalised and resource-intensive form of coproduction (Joshi and Moore 2004). Importantly, and in line with the recent, more critical applications of coproduction concepts (Mitlin 2008; Albrechts 2013; McMillan, Spronk and Caswell 2014), the cooperatives represent a vehicle for citizens to empower themselves by becoming co-owners and influencing the policy and practice of the grid operators. While implementing the cooperative model would imply the involvement of citizens as shareholders and co-owners of the grid operating utility, it would by virtue of its decision-making and revenue distribution regulations create a kind of community (Albrechts 2013) of co-owners; one that is, however, clearly not identical with the group of infrastructure users.

These three types of coproduction describe different ways in which citizens are getting involved in the governance of networked infrastructures in the two cities of Berlin and Hamburg. They signify different degrees of institutionalisation, durability and citizen entitlements. Using coproduction as a heuristic has helped us to identify these different forms. The type of cooperative co-ownership promoted in both cities also resonates with recent conceptualisations of coproduction that encompass empowerment. However, this perspective on coproduction has its limitations, as it does not consider the contexts and characteristics of the services provided. Referring to ownership, for example, the cooperatives can be seen as a means to achieve coproduction, yet how these models of collective ownership might actually transform the nature of public services is not made explicit. We therefore now apply the lens of urban commons to see how this perspective can broaden our understanding of the 
initiatives.

\subsection{Beyond coproduction: energy utilities as a form of commoning}

Analysing the various initiatives in Berlin and Hamburg from a coproduction perspective reveals different ways of organising citizens' involvement. The aspirations of most of the initiatives, however, extend beyond the simple involvement of citizens: they question the provision of energy by private enterprises and highlight issues of social justice. We argue here that these issues are better understood from the perspective of urban commons (Blomley 2008, Harvey 2012, Kip 2015). In applying the urban commons concept to interpret the initiatives in Berlin and Hamburg we will briefly discuss two features of urban commons most prevalent in these cases: firstly, commons as a means of de-privatisation and decommodification and, secondly, new imaginaries of infrastructure and urban governance that challenging conventional policies. These two features help broaden the coproduction perspective by addressing important context-related arguments articulated by the initiatives.

\section{Urban energy commons: deprivatising energy utilities, decommodifying energy provision}

One core term in the discussion of the commons is the idea of a common wealth as a sphere that is exterior to capital accumulation (Hardt and Negri 2009), yet endangered by processes of enclosure and capitalisation (Harvey 2012, 74ff.). Therefore, beyond the issues of ownership and the efforts to deprivatise energy networks, the initiatives proposed a model of non-commodified energy provision that is concerned less with goals of profit-maximising than with sustainability and social justice. All of the initiatives aim at increasing generation of renewable energy in their respective cities. The generation of renewable energy, it is argued, helps achieve the cities' climate policy targets and, especially in the face of major fossil power stations planned in Hamburg (and Berlin), produces a cleaner energy system with a lower environmental impact on the city. Social justice issues were also relevant in the referendum campaigns, where energy poverty was addressed as a new political topic in the German context. Socially-fair pricing schemes played an important role in the communication strategy of the Roundtable and their attempts to convince voters. How far social justice will be addressed by the newly founded public grid operator in Hamburg remains to be seen.

On a more conceptual level, the postulation of taking control over infrastructure services can be a first step to questioning a market-based and commodified mode of infrastructure provision. Different metaphors of appropriation, as in 'Our Hamburg, Our Network', underscore this line of reasoning. The main argument here was that infrastructure for energy provision should be demarcated from market logics. In the view of the initiatives studied, 
energy provision should be transformed from a service operated by private companies into a common good owned by the people of the city.

The creation of urban commons is often discussed in the context of alternative practices that envisage new ways of thinking about and managing a shared resource. With our examples from the field of urban energy systems, these practices mainly take the shape of alternative, collective forms of ownership. If implemented, they would push back private ownership (Parr 2015 ) in some of the most basic infrastructures of urban production and consumption. In this sense, it is only logical that they have formulated clear alternatives to privatised energy grid operation.

The initiatives propose different models of collective ownership of energy networks. Within the cooperative solution, this would consist of the sum of cooperative members, irrespective of their location or the amount of capital they provide. With the participatory public utilities, commoning would have a more indirect character, mediated through public ownership. Here, one could argue that the entire citizenry, defined by the right to vote, would become part of the community. For this to make a difference, however, full use of the various participatory provisions would need to be mobilised. Democratic control and direct participation has already played an important role in the campaigns for remunicipalisation in Berlin and Hamburg. Especially in Berlin, the Berlin Energy Roundtable was characterised by grassroots participation and consensus decision-making. Another factor, obviously, is that the referenda are not only a means of direct, plebiscitary democracy themselves; they have also raised awareness and opened the debate about future energy provision in the cities.

\section{Challenging the status quo of energy provision, articulating new imaginaries for urban governance}

The creation of urban commons is not only connected with new forms of ownership and a fundamental reframing of the provided service. It entails also new imaginaries about urban governance in and beyond the energy sector. As De Angelis argues, commons can serve as a platform for envisioning and developing an alternative framework for social relations and social practices (2003 cited in Eizenberg 2012, 766). Both the referenda and the cooperatives envision future energy provision that is oriented towards democratic governance, ecological sustainability and social justice. All of these break with managerial-style decision-making and purely economic imperatives that dominated past energy policy and urban governance in general. Additionally, the broad discourse on the future of the local energy grids in both cities has raised public interest in energy policy. However, in both cases it was the decision to push for a referendum, with the strategy of conflict escalation it enabled, that stirred intensive public debate, thereby repoliticising this field of urban governance (Beveridge, Hüesker, and 


\section{S. Becker et al.}

Naumann 2014).

The extent of this repoliticisation can be observed in both the concerned reactions of the city governments, business associations and also trade unions (for a detailed analysis see Becker, Beveridge and Naumann 2015, 82f.) and the changes that resulted from the pressure exerted by the campaigns. These include not only the partial creation of public ownership in Hamburg in 2011 and the foundation of Berlin Energie, but also ongoing administrative turf-battles around the future of the gas networks in Berlin. In Hamburg, the installation of participatory discussion fora can also be attributed to the pressure built up by the referendum.

Putting these developments in a broader urban context, the energy campaigns in both cities are closely connected with social movements for a "Right to the City", which address issues of gentrification, rising rents and the preservation of public spaces or resist prestigious projects of urban redevelopment (Beveridge and Naumann 2016). This can be observed, for example, in the involvement of social movements backing these urban causes, such as tenants associations, in the referendum campaigns. A further example is the way the campaign in Berlin highlighted issues of energy poverty, thus connecting their claims for a remunicipalisation of the electricity grid to wider debates about social polarisation conducted within the city's social movements (Interview Activist). In Hamburg, there was a conscious attempt to include many social movements and civil society players when drafting the resolution to support the referendum (Interview OHON campaigner). In Berlin, this tactical alliance-building was reflected in the debates on the draft law for the referendum, too (Interview Roundtable Activist).

As argued above, commons are 'constantly under threat of being enclosed and become a generative force of capitalist reproduction' (Eizenberg 2012, 779). In that sense the commoning of energy provision in Berlin and Hamburg is still an open process. It is this more far-reaching perspective of commoning, embracing alternative visions and contested futures of collective governance, that fully grasps the significance of the cities' energy initiatives as they strive to deprivatise energy provision. While we acknowledge the way the coproduction concept emphasises citizen involvement, the perspective of urban commons can enrich our understanding of the political and economic contexts that motivate citizens to become active in shaping urban energy futures.

\section{Conclusion}

This paper began with the widely established observation that energy transitions not only decentralise physical infrastructures of generation and distribution, but also bring to the fore new kinds of actors - such as citizens, farmers or other small and medium enterprises - that 
become energy providers: coproducers of energy services. While these findings correspond well with the general understanding of coproduction as the enrolment of new actors and their resources (Brandsen and Pestoff 2006), this paper has set out to broaden this perspective. Using the cases of Berlin and Hamburg, we looked at how social movements proposed new models for energy utilities that were built around collective or participatory public ownership, thereby challenging the status-quo of urban energy provision.

Our empirical findings in Berlin and Hamburg reaffirm how energy transitions enrol new actors in urban energy provision. Beyond this, however, we have demonstrated how, in both cities, this involvement of citizens and other stakeholders in local energy policies was connected to a debate on new - public or cooperative - forms of ownership of energy utilities. Furthermore, the campaigns for remunicipalisation in Berlin and Hamburg stand as examples of fundamental contestation over urban governance, in that they demanded an ecologically sustainable, socially just and de-commodified urban energy utility, signifying a sharp break with neoliberal understandings how cities (and their services) should be governed.

Analysing these cases we used the concept of coproduction as a heuristic tool to consider how it helps us to understand these forms of ownership and citizen involvement as well as alternative ideas for governing urban energy utilities. Beyond that, we discussed how the notion of urban commons could extend the perspective on coproduction conceptually. We argue that coproduction is able to grasp a number of issues related to the participation and involvement of citizens in the field of energy provision. However, there is a need, in addition, to consider the broader implications of these ownership changes, such as how they can transform the commodity character of infrastructure and energy, and the underlying visions of urban governance. We have argued that these issues are captured better with a critical understanding of commons. On the basis of our findings, we conclude by mapping out promising avenues for future research.

Social movements and citizen initiatives as coproducers in urban energy provision. We were able to identify different types of coproduction in the energy sector of Berlin and Hamburg. These include a) coproduction on a project scale which is a temporary (or permanent) form of cooperation based on joint investments in renewable energy facilities, b) coproduction through formalised bodies of participation within energy utilities, e.g. advisory boards, and c) coproduction through co-owning as it is prevalent in the energy cooperatives in both cities. In line with the core meaning of coproduction all of these three types share a new - more active - role of citizens in urban energy provision and challenge the former dichotomy of consumer vs. producer, thereby deserving more scholarly attention.

Energy utilities as urban commons. The (re)establishment of public utilities as proposed by the referenda in both cities was a way to de-privatise energy provision and transform it from a 
commodity to a public good accessible for every citizen and amenable to ecological aims rather than a profit-maximising logic. In that sense, urban energy utilities can be understood as urban commons and as an element of urban governance which can be used to develop alternatives to neoliberal urbanism. This highlights the highly contested nature of the production of urban commons and directs future research to investigating attempts at commoning urban energy systems as deeply political processes.

Beyond coproduction and commons. The approaches of coproduction and urban commons highlight different elements of urban energy movements. With their different, yet complementary, foci, both concepts can raise our understanding of citizen participation in energy provision and beyond. A promising line of enquiry would be to explore which elements of energy provision (or other urban services) lend themselves to coproduction, which to urban commoning and which to neither of the two. Since coproduction and commons cannot be limited to certain policy sectors, the analysis of citizen participation in urban energy has to be addressed in consideration of broader urban contexts. Infrastructural issues are inseparably connected to spatial issues. We have argued here that coproduction and commons could provide a fruitful dual framework to guide research on infrastructure provision from the perspective of critical urban theory.

\section{Acknowledgement and Funding}

This paper is based on preliminary findings from the project ENERLOG funded by the German Federal Ministry for Education and Research (BMBF) under Grant 01UN1207B and independent scientific work of the corresponding author. We assure that there is no conflict of interest involved in its production. 


\section{References}

Albrechts, Louis. 2013. "Reframing Strategic Spatial Planning by Using a Coproduction Perspective.” Planning Theory 12 (1): 46-63. doi:10.1177/1473095212452722.

Alford, John. 1998. "A Public Management Road Less Travelled: Clients as Co-producers of Public Services.” Australian Journal of Public Administration 57 (4): 128-37. doi:10.1111/j.1467-8500.1998.tb01568.x.

Angelis, Massimo de. 2003. "Reflections on Alternatives, Commons and Communities." The Commoner (6): 1-14. http://www.commoner.org.uk/deangelis06.pdf.

attac Berlin, BürgerBegehren Klimaschutz, and PowerShift. 2011. "Neue Energie für Berlin Netze in Bürgerhand." http://power-shift.de/wordpress/wpcontent/uploads/2011/05/Brosch\%C3\%Bcre-NeueEnergieNetzeInB\%C3\%BcrgerhandBerlin-2Aufl-7-2011.pdf.

Bakker, Karen. 2007. "The "Commons" Versus the "Commodity": Alter-globalization, Antiprivatization and the Human Right to Water in the Global South." Antipode 39 (3): 430-55. doi:10.1111/j.1467-8330.2007.00534.x.

Bauer, Hartmut. 2012. "Von der Privatisierung zur Rekommunalisierung: Einführende Problemskizze.” In Rekommunalisierung öffentlicher Daseinsvorsorge, edited by Hartmut Bauer, Christiane Büchner, and Lydia Hajasch, 11-33. Potsdam: Universitätsverlag.

Bauriedl, Sybille and Markus Wissen. 2002. "Post-Fordist transformation, the sustainability concept and social relations with nature: a case study of the Hamburg region." Journal of Environmental Policy and Planning 4 (2): 107-21. doi: 10.1002/jepp.107.

Becker, Sören, Ross Beveridge, and Matthias Naumann. 2015. "Remunicipalization in German Cities: Contesting Neo-Liberalism and Reimagining Urban Governance?" Space and Polity 19 (1): 76-90. doi:10.1080/13562576.2014.991119.

Behörde für Inneres und Sport Hamburg. 2014. "Volksentscheid Energienetze: Endgültiges Ergebnis festgestellt." http://www.hamburg.de/wahlen/4125972/ergebnis-volksentscheidenergienetze/.

Berliner Energietisch. 2012. "Neue Energie für Berlin: Eckpunkte des Gesetzentwurfs für eine demokratische, ökologische und soziale Energieversorgung." http://www.berlinerenergietisch.net/images/eckpunktepapier\%20ge.pdf.

Berlo, Kurt, and Oliver Wagner. 2013. "Stadtwerke-Neugruendungen und Rekommunalisierungen: Energieversorgung in kommunaler Verantwortung.” Unpublished manuscript, last modified May 12, 2014.

Beveridge, Ross, Frank Hüesker, and Matthias Naumann. 2014. "From Post-Politics to a Politics of Possibility? Unravelling the Privatization of the Berlin Water Company." Geoforum 51: 66-74. doi:10.1016/j.geoforum.2013.09.021

Beveridge, Ross, and Matthias Naumann (2016, forthcoming): Another urban infrastructure is possible: contesting energy and water networks in Berlin. In Beyond the Networked City. 
Infrastructure reconfigurations and urban change in the North and South, edited by Olivier Coutard and Jonathan Rutherford. London and New York: Routledge.

Blanchet, Thomas. 2015. "Struggle Over Energy Transition in Berlin: How Do Grassroots Initiatives Affect Local Energy Policy-Making?” Energy Policy 78: 246-54. doi:10.1016/j.enpol.2014.11.001

Blomley, Nicholas. 2008. "Enclosure, Common Right and the Property of the Poor." Social \& Legal Studies 17 (3): 311-31. doi:10.1177/0964663908093966.

Bontrup, Heinz-J., and Ralf-M. Marquardt. 2010. Kritisches Handbuch der deutschen Elektrizitätswirtschaft: Branchenentwicklung, Unternehmensstrategien, Arbeitsbeziehungen. Berlin: Edition Sigma.

Borenstein, Severin. 2012. "The Private and Public Economies of Renewable Electricity Generation." The Journal of Economic Perspectives 26 (1): 67-92. doi: 10.1257/jep.26.1.67.

Bovaird, Tony. 2007. "Beyond Engagement and Participation: User and Community Coproduction of Public Services." Public Administration Review 67 (5): 846-60. doi:10.1111/j.1540-6210.2007.00773.x.

Brandsen, Taco, and Victor Pestoff. 2006. "Co-Production, the Third Sector and the Delivery of Public Services.” Public Management Review 8 (4): 493-501. doi:10.1080/14719030601022874.

Bromley, Daniel W. 1991. Environment and Economy: Property Rights and Public Policy. Oxford: Blackwell.

Brudney, Jeffrey L., and Robert E. England. 1983. "Toward a Definition of the Coproduction Concept." Public Administration Review 43 (1): 59-65. doi:10.2307/975300.

Bruns, Elke, and Dörte Ohlhorst. 2011. "Wind Power Generation in Germany: A Transdisciplinary View on the Innovation Biography." The Journal of Transdisciplinary Environmental Studies 10 (1): 45-67.

Bulkeley, Harriet, Vanesa C. Broto, and Gareth A. Edwards. 2014. An Urban Politics of Climate Change: Experimentation and the Governing of Socio-Technical Transitions. Abingdon, New York: Routledge.

Burger, Christoph, and Jens Weinmann. 2012. The Decentralized Energy Revolution: Business Strategies for a New Paradigm. Basingstoke: Palgrave Macmillan.

Calabrò, Andrea. 2012. "Co-Production: An Alternative to the Partial Privatization Processes in Italy and Norway." In New public governance, the third sector and co-production, edited by Victor A. Pestoff, Taco Brandsen, and Bram Verschuere, 317-36. New York: Routledge.

Casa-Cortés, Maribel, Sebastian Cobarrubias, and John Pickles. 2014. "The Commons". In $A$ Companion to Urban Anthropology, edited by Donald Nonini, 449-70, Hoboken: WileyBlackwell. 
Chatterton, Paul. 2010. "Seeking the urban commons: Furthering the debate on spatial justice." City 14 (6), 625-28. doi:10.1080/13604813.2010.525304.

Couture, Toby, and Yves Gagnon. 2010. “An Analysis of Feed-In Tariff Remuneration Models: Implications for Renewable Energy Investment.” Energy Policy 38 (2): 955-65. doi:10.1016/j.enpol.2009.10.047.

Cumbers, Andrew. 2015. "Constructing a Global Commons In, Against, and Beyond the State." Space and Polity 19 (1): 62-76. doi:10.1080/13562576.2014.995465.

Cumbers, Andrew. 2012. Reclaiming Public Ownership: Making Space for Economic Democracy. London: Zed Books.

Dietz, Thomas, Nives Dolšak, Elinor Ostrom, and Paul C. Stern. 2002. "The Drama of the Commons." In The Drama of the Commons, edited by Elinor Ostrom, Thomas Dietz, Nives Dolšak, and Paul C. Stern, 3-35. Washington: National Academy Press.

Eizenberg, Efrat. 2012. "Actually Existing Commons: Three Moments of Space of Community Gardens in New York City." Antipode 44 (3): 764-82. doi:10.1111/j.14678330.2011.00892.x.

Eurostat. 2015. "Share of renewables in energy consumption up to $15 \%$ in the EU in 2013." 2015. News release. March 10. http://ec.europa.eu/eurostat/documents/2995521/6734513/810032015-AP-EN.pdf/3a8c018d-3d9f-4f1d-95ad-832ed3a20a6b.

Evans, Peter. 1996. "Introduction: Development Strategies across the Public-Private Divide." World Development 24 (6): 1033-7. doi:10.1016/0305-750X(96)00014-9.

Fennell, Lee A. 2011. "Ostrom's Law: Property rights in the commons.” International Journal of the Commons 5 (1): 9-27. doi: 10.18352/ijc.252.

Hahnel, Robin. 2015. "Participatory Economics and the Commons." Capitalism Nature Socialism 26 (3): 31-43. doi: 10.1080/10455752.2015.1011069.

Hall, David, Emanuele Lobina, and Philipp Terhorst. 2013. "Re-Municipalisation in the Early Twenty-First Century: Water in France and Energy in Germany." International Review of Applied Economics 27 (2): 193-214. doi:10.1080/02692171.2012.754844.

Hamburg Wasser, and Hamburg Energie. 2014. "Geschäftsbericht".

Hardt, Michael, and Antonio Negri. 2009. Commonwealth. Cambridge: Belknap Press of Harvard University Press.

Harvey, David. 2011. “The Future of the Commons.” Radical History Review 109: 101-7. doi:10.1215/01636545-2010-017.

Harvey, David. 2012. Rebel Cities: From the Right to the City to the Urban Revolution. London: Verso.

Helfrich, Silke, and David Bollier. 2012. "Commons als transformative Kraft." In Commons. Für eine neue Politik jenseits von Markt und Staat edited by Helfrich and Heinrich-BöllStiftung, 15-23, Bielefeld: transcript. 
Hess, David. 2011. "Electricity Transformed: Neoliberalism and Local Energy in the United States." Antipode 43 (3), 1056-77. doi: 10.1111/j.1467-8330.2010.00842.x.

Hisschemöller, Matthijs, and Ino Sioziou. 2013. "Boundary organisations for resource mobilisation: enhancing citizens' involvement in the Dutch energy transition." Environmental Politics 22 (5): 792-810. doi:10.1080/09644016.2013.775724.

Hodkinson, Stuart. 2012. "The new urban enclosures." City 16 (5), 500-18. doi:10.1080/13604813.2012.709403.

Jeffrey, Alex, Colin McFarlane, and Alex Vasudevan. 2012. "Rethinking Enclosure: Space, Subjectivity and the Commons." Antipode 44 (4): 1247-67. doi:10.1111/j.14678330.2011.00954.x.

Jenny, Annette, Fernando Hechavarria Fuentes, and Hans-Joachim Mosler. 2007.

"Psychological Factors Determining Individual Compliance with Rules for Common Pool Resource Management: The Case of a Cuban Community Sharing a Solar Energy System." Human Ecology 35 (2): 239-50. doi:10.1007/s10745-006-9053-x.

Jenssen, Till, Andreas König, and Ludger Eltrop. 2014. "Bioenergy villages in Germany: Bringing a low carbon energy supply for rural areas into practice." Renewable Energy 61: 74-80. doi:10.1016/j.renene.2012.08.014.

Joshi, Anuradha, and Mick Moore. 2004. "Institutionalised Co-production: Unorthodox Public Service Delivery in Challenging Environments." Journal of Development Studies 40 (4): 31-49. doi:10.1080/00220380410001673184.

Kip, Markus. 2015. "Moving Beyond the City: Conceptualizing Urban Commons from a Critical Urban Studies Perspective.” In Urban Commons: Moving Beyond State and Market, edited by Mary Dellenbaugh, Markus Kip, Majken Bienok, Agnes Katharina Müller, and Martin Schwegmann, 42-60, Basel: Birkhäuser.

Klein, Naomi. 2001. "Reclaiming the Commons." New Left Review 9: 81-89. $\mathrm{http} / / /$ newleftreview.org/II/9/naomi-klein-reclaiming-the-commons.

Krätke, Stefan. 2001. “Berlin: Towards a Global City?” Urban Studies 38 (10): 1777-99. doi: 10.1080/00420980120084859.

Kunze, Conrad, and Sören Becker. 2015. "Collective Ownership in Renewable Energy and Opportunities for Sustainable Degrowth.” Sustainability Science 10 (3): 425-37. doi: 10.1007/s11625-015-0301-0

Landeswahlleiterin Berlin. 2013. "Volksentscheid "Neue Energie" am 3. November 2013: Ergebnis des Volksentscheids." https://www.wahlenberlin.de/Abstimmungen/VE2013_NEnergie/Ergebnisprozent.asp?sel1=6052\&sel2=0798.

Linebaugh, Peter. 2008. The Magna Carta Manifesto: Liberties and Commons for All. Berkeley: University of California Press.

Matecki, Claus, and Thorsten Schulten. 2013. "Zwischen Privatisierung und Rekommunalisierung: Zur Entwicklung der öffentlichen Daseinsvorsorge." In Zurück zur 
öffentlichen Hand? Chancen und Erfahrungen der Rekommunalisierung, edited by Claus Matecki and Thorsten Schulten, 8-18. Hamburg: VSA-Verlag.

Mayer, Margit. 2012. "The 'right to the city' in urban social movements." In Cities for People, Not for Profit: Critical Urban Theory and the Right to the City, edited by Neil Brenner, Peter Marcuse, and Margit Mayer, 42-61. London and New York: Routledge.

McDonald, David A. and Greg Ruiters (eds.). 2012. Alternatives to Privatisatization: Public Options for Essential Services in the Global South. London: Routledge.

McMillan, Rebecca, Susan Spronk, and Calais Caswell. 2014. "Popular Participation, Equity, and Co-Production of Water and Sanitation Services in Caracas, Venezuela." Water International 39 (2): 201-15. doi:10.1080/02508060.2014.886844.

Meyer-Wellmann, Jens. 2014. "Nach Vattenfall-Deal: das passiert jetzt mit dem Netz." Hamburger Abendblatt, January 16.

Mitlin, Diana. 2008. "With and Beyond the State: Co-Production as a Route to Political Influence, Power and Transformation for Grassroots Organizations." Environment and Urbanization 20 (2): 339-60. doi:10.1177/0956247808096117.

Moss, Timothy. 2014. "Socio-technical Change and the Politics of Urban Infrastructure: Managing Energy in Berlin between Dictatorship and Democracy." Urban Studies 51 (7): 1432-48. doi: 10.1177/0042098013500086.

Moss, Timothy, Sören Becker, and Matthias Naumann. 2014. "Whose Energy Transition Is It, Anyway? Organisation and Ownership of the Energiewende in Villages, Cities and Regions." Local Environment, online first 19 May 2014. doi:10.1080/13549839.2014.915799.

Nielsen, Søren N., and Sven E. Jørgensen. 2014. "Sustainability Analysis of a Society Based on Exergy Studies: A Case Study of the Island of Samsø (Denmark)." Journal of Cleaner Production 96 (1): 12-29. doi:10.1016/j.jclepro.2014.08.035.

Norddeutscher Rundfunk. 2014. "Kraftwerk Moorburg: eine Chronologie." http://www.ndr.de/nachrichten/dossiers/kohlekraft/moorburgchronologie100_page-1.html.

Olson, Mancur. 1965. The Logic of Collective Action: Public Goods and The Theory of Groups. Cambridge: Harvard University Press.

Osborne, Stephen P., and Kirsty Strokosch. 2013. "It takes Two to Tango? Understanding the Co-production of Public Services by Integrating the Services Management and Public Administration Perspectives." British Journal of Management 24 (S1): S31-S47. doi:10.1111/1467-8551.12010.

Ostrom, Elinor. 1972. "Metropolitan Reform: Propositions Derived From Two Traditions." Social Science Quarterly 53: 474-93.

Ostrom, Elinor. 1990. Governing the Commons: The Evolution of Institutions for Collective Action. Cambridge: Cambridge University Press. 
Ostrom, Elinor. 1996. "Crossing the Great Divide: Coproduction, Synergy, and Development.” World Development 24 (6): 1073-87. doi:10.1016/0305-750X(96)00023-X.

Ostrom, Elinor. 2005. Understanding Institutional Diversity. Princeton: Princeton University Press.

Ostrom, Elinor. 2008. "The Challenge of Common-Pool Resources." Environment: Science and Policy for Sustainable Development 50 (4): 8-21. doi: 10.3200/ENVT.50.4.8-21

Ostrom, Elinor. 2010. "Beyond Markets and States: Polycentric Governance of Complex Economic Systems." American Economic Review 100 (3): 641-72. doi:10.1257/aer.100.3.641.

Ostrom, Elinor, and Gordon Whitaker. 1973. "Does Local Community Control of Police Make a Difference? Some Preliminary Findings." American Journal of Political Science 17 (1): 48-76. doi:10.2307/2110474.

Ostrom, Elinor, Roger B. Parks, and Gordon P. Whitaker. 1974. "Defining and Measuring Structural Variations in Interorganizational Arrangements." Publius 4 (4): 87-108. doi: $10.2307 / 3329480$.

Parr, Adrian. 2015. "Urban Debt, Neoliberalism and the Politics of the Commons". Theory, Culture \& Society 32 (3), 69-91. doi:10.1177/0263276414536234.

Peck, Jamie. 2010. Constructions of Neoliberal Reason. Oxford: Oxford University Press.

Pestoff, Victor A. 2009. A Democratic Architecture for the Welfare State. London: Routledge.

Radywyl, Natalia and Che Biggs. 2013. "Reclaiming the commons for urban transformation." Journal of Cleaner Production 50: 159-70. doi:10.1016/j.jclepro.2012.12.020.

Rügemer, Werner. 2006. Privatisierung in Deutschland: Eine Bilanz von der Treuhand zu Public Private Partnership. Münster: Westfälisches Dampfboot.

Schlager, Edella, and Elinor Ostrom. 1992. "Property-Rights Regimes and Natural Resources: A Conceptual Analysis." Land Economics 68 (3): 249-62.

Senatskanzlei Freie und Hansestadt Hamburg. 2011. "Hamburg schafft die Energiewende." 2011. News release. November 29. http://www.hamburg.de/pressearchivfhh/3168428/2011-11-29-energiewende/.

Sühlsen, Kathrin, and Matthijs Hisschemöller. 2014. "Lobbying the 'Energiewende'. Assessing the Effectiveness of Strategies to Promote the Renewable Energy Business in Germany." Energy Policy 69: 316-25. doi: 10.1016/j.enpol.2014.02.018.

Susser, Ida, and Stéphane Tonnelat. 2013. "Transformative cities: The three urban commons." Focaal. Journal of Global and Historical Anthropology 66, 105-32. doi: 10.3167/fcl.2013.660110.

Trend:Research, and Leuphana University Lüneburg. 2013. "Definition und Marktanalyse von Bürgerenergie in Deutschland." http://100-prozent-erneuerbar.de/wpcontent/uploads/2013/10/Definition-und-Marktanalyse-von-B\%C3\%Bcrgerenergie-inDeutschland.pdf. 
Vermeylen, Saskia. 2010. "Resource Rights and the Evolution of Renewable Energy Technologies.” Renewable Energy 35 (11): 2399-2405. doi:10.1016/j.renene.2010.03.017.

Verschuere, Bram, Taco Brandsen, and Victor Pestoff. 2012. "Co-production: The State of the Art in Research and the Future Agenda." Voluntas 23 (4): 1083-1101. doi:10.1007/s11266012-9307-8.

Von Winterfeld, Uta, Adelheid Biesecker, Christine Katz, and Benjamin Best. 2012. Welche Rolle können Commons in Transformationsprozessen zu Nachhaltigkeit spielen? Wuppertal: Wuppertal Institut für Klima, Umwelt, Energie.

Wolsink, Maarten. 2012. "The Research Agenda on Social Acceptance of Distributed Generation in Smart Grids: Renewable as Common Pool Resources." Renewable and Sustainable Energy Reviews 16 (1): 822-35. doi: HYPERLINK "http://dx.doi.org/10.1016/j.rser.2011.09.006" \n_blank10.1016/j.rser.2011.09.006.

Yildiz, Özgür, Jens Rommel, Sarah Debor, Lars Holstenkamp, Franziska Mey, Jakob R. Müller, Jörg Radtke, and Judith Rognli. 2015. "Renewable Energy Cooperatives as Gatekeepers or Facilitators? Recent Developments in Germany and a Multidisciplinary Research Agenda." Energy Research \& Social Science 6: 59-73. doi:10.1016/j.erss.2014.12.001.

Zawatka-Gerlach, Ulrich, Lars v. Törne, and Fatima Keilani. 2014. "Das ist fürchterlich für die Koalition: Senator Heilmann gegen Senator Nussbaum.” Tagesspiegel, June 25. http://www.tagesspiegel.de/berlin/senator-heilmann-gegen-senator-nussbaum-das-istfuerchterlich-fuer-die-koalition/10095942.html.

Zawatka-Gerlach, Ulrich. 2015. "Senat will sich an Gas- und Stromunternehmen beteiligen: Streit um Energienetze vorerst beigelegt." Tagesspiegel, May 5.

http://www.tagesspiegel.de/berlin/berlin-streit-um-energienetze-vorerst-beigelegt-senatwill-sich-an-gas-und-stromunternehmen-beteiligen/11733656.html. 


\section{Appendix: List of interviews referred to in the text}

Interview BUND: Interview with a representative of Bund für Umwelt- und Naturschutz Deutschland [Friends of the Earth Germany]. Hamburg 16 December 2014.

Interview BürgerEnergie: Interview with a spokeswoman of BürgerEnergie Berlin. Berlin 2 September 2013.

Interview Church: Interview with a Hamburg Diakonie representative [charity organisation of the Protestant-Lutheran Church]. Berlin 20 June 2014.

Interview Councellor: Interview with a councellor who was officially engaged with the formation Hamburg Energie. Hamburg 20 April 2015.

Interview Handelskammer: Interview with a leading employee of Handelskammer Hamburg [Chamber of Commerce Hamburg]. 17 December 2014.

Interview OHON Campaigner: Interview with a professional campaigner active for the 'Our Hamburg - Our Network' (OHON) campaign. Hamburg 8 January 2015.

Interview Roundtable Activist: Interview with a left-winged grassroots activist from the Berlin Energy Roundtable. Berlin 28 August 2013.

Interview Roundtable Professional: Interview with a professional campaigner coordinating the Roundtable's campaign activities. Berlin 27 August 2013.

Interview SPD Environment: Interview with a high-ranking member of SPD Hamburg specialised in environmental politics. Hamburg 26 March 2015.

Interview Zukunftsrat: Interview with a leading member of the network Zukunftsrat Hamburg [Future Council Hamburg - Network for Sustainable Development]. Hamburg 8 April 2015. 